\title{
The Effect of Write Pair Switch Method To The Ability Of Mathematical Communication and Student Learning Interaction in Class V SD Swasta Nurul Hasanah
}

\author{
Elly Nurhayati Purba ${ }^{1)}$ \\ Postgraduate School of the State University of Medan \\ Basic Edication \\ Medan, Indonesian \\ ellyumnafanto@gmail.com
}

\author{
Dian Armanto $^{2)}$, Aman Simaremare ${ }^{3)}$ \\ Postgraduate School of the State University of Medan \\ Department of Math Education \\ Medan, Indonesian
}

\begin{abstract}
The purpose of this research is to know effect of write pair switch method to the ability of mathematical communication and student learning interaction. The research is planned to be implemented in the even semester of academic year 2017/2018, at Nurul Hasanah Elementary School Percut Sei Tuan Subdistrict Deli Serdang Regency. The sample in this research is Class $\mathrm{V}-\mathrm{A}$ and $V$-B which amounts to 38 students, which is given by using Write Pair Switch method with each group consist of 10 students and given by using Write Pair Switch method with each group consist of 6 students. This type of research is quasi experiment (quasi experiment) because the class used has been formed before. Based on the results of the analysis and findings of researchers from the field obtained some conclusions that are the answers to the questions on the formulation of the problem, including the influence of Write Pair Switch learning methods to students mathematical communication skills. With ANCOVA test obtained significant number 0,047. The influence of learning method of Write Pair Switc to study interaction With ANCOVA test obtained significant number 0,028 . There is a difference in the process of student responses in Mathematical Communication Skills in groups of 6 students and groups of 10 students. There is a different process of student learning interaction in groups consisting of 6 students and a group of 10 students.
\end{abstract}

Keywords: Ability of Mathematical Communication, Student Learning Interaction, Write Pair Switch

\section{INTRODUCTION}

In education, students are the goal and the most preferred subject. Changes in attitudes experienced by themselves are educational goals, while the core of the implementers of education are students not educators. Without educators, one can still learn and experience change, so students are said to be subjects of education. By getting education, people can get knowledge that can be useful for their survival and can know how to respond to life [10].

Teaching and learning interactions have a purpose to help children in a particular development. According to Vygotsky [2], believes that the interaction of children with others through the most powerful language influences the level of conceptual understanding that children can achieve and strongly believes that someone can learn from other people both the same age and older and have higher level of development. In this case the teacher is the dominant factor for achieving education and teaching goals. Therefore a teacher is required to be able to put himself in rhythm with the ongoing teaching and learning activities. Concretely the task of the teacher in teaching and learning activities is to educate and teach his students by guiding, providing guidance, being an exemplary figure and providing assistance to skills, skills, values, moral norms, truth, honesty, attitudes and good and commendable qualities and so on. This is consistent with the results of research conducted [10] which proves that the interaction made by students who excel in individual learning is better.

Mathematics is a part of science with various roles in the formation of the quality of human resources and is often used in everyday life. MKPBM TEAM [1] argues that one of the lessons taught at school aims to help students prepare themselves to be able to deal with changes in life and the everevolving world, through the practice of acting on a logical basis, rational and critical.

According to Sibuea et al [11] mathematics is one of the branches of science and technology, both as an aid tool in the application of other fields of science and in the development of mathematics itself. Mathematics is a science that has special characteristics, one of which is deductive reasoning with regard to ideas, concepts, and symbols that are abstract and comprehensively arranged, so that learning activities can be handled specifically [11].

However, in fact in learning activities only active teachers and students are passive, ie students only listen to the 
explanation of the teacher diligently. The impact causes students to daydream, sleepy, listen while playing stationery, and occasionally make ignorance. This fact is similar to the results of Goodlad's research [5], which proves that more than 1000 classes argue that it is very popular that a teacher only stands in front of the class while conveying knowledge to students. Smith [5] also wrote that nearly $90 \%$ of teachers spoke during the lesson. Even Frey, Fisher and Allen [5] observe that students are only expected to sit for hours, take notes, and answer questions occasionally with little interaction with peers.

Rosyada [2] said that until now, the reality in the field, there were still many teachers adhering to the paradigm of transfer of knowledge (learning without heart) in learning and emphasizing more on the practice of doing routine questions and drills. And if we continue to embrace a paradigm like this it will cause our school education results to only be able to produce young people who lack self-awareness, lack critical thinking, are less creative, are less independent, and lack communication widely with the social environment in life.

To overcome this, then in the learning process must be changed, which is one of them by involving students actively in learning and teachers as facilitators to achieve mathematics learning goals. According to Wittgenstein [2] an educational program is needed that can develop the ability to think critically, systematically, logically and creatively. One education program that can develop these abilities is mathematics. Understanding mathematics can make us find answers to problems faced by humans, a way of using information, using knowledge about shapes and sizes, using knowledge about counting, and the most important thing is to think in humans themselves in seeing and using relationships [2].

One learning model that is felt appropriate in improving mathematical communication skills is cooperative learning. Experts such as Johnson, et al, Johnson and Johnson, Slavin, and Sharan (in Fitriani and Novitasari, 2017: 2) also argue that cooperative learning models are effective teaching strategies in improving student achievement and socialization while contributing to improving attitudes and perceptions for they are about the importance of learning and working together, including their understanding of friends who come from different ethnic backgrounds.

Cooperative learning is different from other learning strategies. These differences can be seen from the learning process that emphasizes the process of collaboration in groups. Similarly, stated by Woods and Chen (in Purnomo, 2011: 41) that "cooperative learning is instructional in which students work together toward a common goal". The aim to be achieved is not only academic ability, but also the element of cooperation for mastering the material. This collaboration is the characteristic of cooperative learning (Trianto, 2010: 58). Similarly, what was stated by Vigostky and Slavin (in Affifah, 2012: 5) that cooperative learning can improve student activity and make it easier for students to interact with each other to help other students achieve learning goals.
Cooperative learning models will be able to foster effective learning, namely learning characterized by making it easier for students to learn something useful and knowledge, values and skills that are recognized by those who are competent to judge (Suprijono.2009). Many studies have proven that the use of cooperative learning models with various types and strategies of learning can improve student learning outcomes especially towards students' mathematical communication skills. Among them are Fitriani and Novitasari, 2017; Purnama and Afriansyah, 2016; Hadijah and Hasrattudin, 2016; Elida, 2012; and [4] have proven that there is an increase and complete mathematical communication skills $100 \%$ of students achieve KKM.

The Write-Pair-Switch method is one of the latest development methods of the Cooperative Learning model. The Write-Pair-Switch method will create a learning atmosphere that is full of interaction between students and requires the participation of all students. So that the process of mutual interaction and participation among students is expected to help teachers in developing students' mathematical communication skills. In the sense of Indonesian language we can mean that the Write Pair Switch method is a method of Writing, Sharing and Pairing. This method emphasizes group collaboration in interacting with shared understanding with other friends.

Communication and information exchange is not only in the form of verbal but also in the form of writing, so that in addition to facilitating students to express their ideas orally, the Write-Pair-Switch method will also train students to express their mathematical ideas through writing. As the development of the cooperative learning model the Write Pair Switch method has specific principles that become its advantages in the learning process, including Social Skills, Responsibility, Higher Level Thinking Skills, Increased Participation (Kagan, 1999), Heterogeneous Grouping, Collaborative Skills, Autonomy Group , Individual Accountability, Positive Interdependence, Cooperative as a Value [6], Simultaneous Interaction [6] and Participation Communication (Sanjaya, 2009). In these principles there is an important aspect in providing students 'understanding to improve students' mathematical communication skills.

\section{RESEARCH METHODS}

\subsection{Research sites}

The research was carried out in the even semester of 2017/2018 school year in Nurul Hasanah Private Elementary School, Percut Sei Tuan District, Deli Serdang Regency. This school has two types of classes, namely PLUS and Regular classes. The school is located on Amal Bakti Street No.69 B Pasar 7 Tembung, District Percut sei hosting Deli Serdang Regency.

The population in this study were all fifth grade students of Nurul Hasanah Tembung Private Elementary School totaling 78 students consisting of 3 classes, namely V-A Class totaling 18 students, V-B totaling 20 students and V-C totaling 40 students. The sampling was carried out using purposive sampling technique. The sample in this study is class plus, namely class $\mathrm{V}-\mathrm{A}$, which amounts to 18 students and class $\mathrm{V}$ - 
B totaling 20 students, who will be given learning by the same method namely Write Pair Switch.

\subsection{Research design}

This type of research is quasi experiment (quasiexperimental) because the class used has been formed before.

\begin{tabular}{|c|c|c|c|}
\hline Treatment group & $\begin{array}{c}\text { Pree } \\
\text { Test }\end{array}$ & Treatmen & Post Tes \\
\hline $\begin{array}{c}\text { Learning with the } \\
\text { Write Pair Switch } \\
\text { Method } \\
\text { consisting of } 6 \\
\text { students / groups }\end{array}$ & $\mathrm{O}_{1}$ & $\mathrm{X}_{1}$ & $\mathrm{O}_{2}$ \\
\hline $\begin{array}{c}\text { Learning with the } \\
\text { Write Pair Switch } \\
\begin{array}{c}\text { Method } \\
\text { consisting of } 10 \\
\text { students / groups }\end{array}\end{array}$ & $\mathrm{O}_{1}$ & $\mathrm{X}_{2}$ & $\mathrm{O}_{2}$ \\
\hline
\end{tabular}

(Source: Modification [2])

\subsection{Data analysis technique}

In connection with the formulation of the problem in this study, in analyzing the data a descriptive statistical analysis was conducted to analyze the student's answer process and inferential statistical analysis by using the SPSS Ver.20 test to analyze the effect of learning with the Write Pair Switch method on Mathematical Communication Ability and Interaction of Elementary Student Learning Private Nurul Hasanah Tembung.

\section{RESEARCH RESULTS AND DISCUSSION}

\subsection{Pretest Mathematical Communication Ability}

For more details, figure 3.1 can be observed in the percentage level of students' mathematical communication skills in the following two classes:

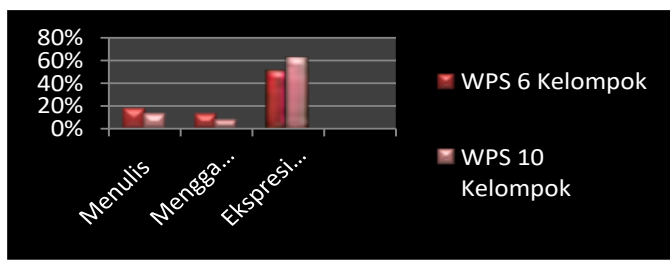

Fig 3.1 Graph of results Pretest indicator of students' mathematical communication skills in class V-A with Write Pair Switch method consisting of 6 students and V-B with Write Pair Switch method consisting of 10 students in the group.

The following data to clarify differences in student learning outcomes in answering math communication questions:

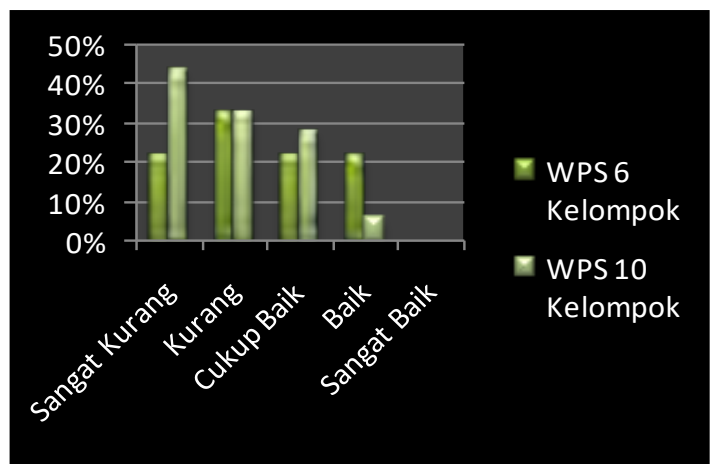

Fig 3.2 Graph of the results of the V-A class student pretest with the Write Pair Switch method consisting of 6 students and V-B with the Write Pair Switch method consisting of 10 students in the group.

It can be concluded that the initial ability of mathematical communication in class $\mathrm{V}-\mathrm{A}$ is better than the group $\mathrm{V}-\mathrm{B}$.

\section{2 .Postest Mathematical Communication Ability}

Mathematical communication skills tests are conducted after learning (posttest). For the description of the results of students' mathematical communication skills, the lowest score, the highest score, the average score and the standard deviation of each experimental class are summarized in the following table:

\section{Descriptives}

\begin{tabular}{|c|c|c|c|c|c|c|c|c|}
\hline & \multirow[t]{2}{*}{$\mathrm{N}$} & \multirow[t]{2}{*}{ Mean } & \multirow{2}{*}{$\begin{array}{l}\text { Std. } \\
\text { Deviati } \\
\text { on }\end{array}$} & \multirow[t]{2}{*}{$\begin{array}{l}\text { Std. } \\
\text { Error }\end{array}$} & \multicolumn{2}{|c|}{$\begin{array}{l}95 \% \text { Confidence } \\
\text { Interval for Mean }\end{array}$} & \multirow[t]{2}{*}{ Min } & \multirow[t]{2}{*}{ Max } \\
\hline & & & & & $\begin{array}{l}\text { Lower } \\
\text { Bound }\end{array}$ & $\begin{array}{l}\text { Upper } \\
\text { Bound }\end{array}$ & & \\
\hline $\begin{array}{l}\text { WP } \\
\text { S6 }\end{array}$ & 18 & 85,17 & 10,667 & 2,514 & 79,86 & 90,47 & 65 & 100 \\
\hline $\begin{array}{l}\text { WP } \\
\text { S10 }\end{array}$ & 20 & 73,45 & 16,070 & 3,593 & 65,93 & 80,97 & 35 & 100 \\
\hline Tota & 38 & 79,00 & 14,834 & 2,406 & 74,12 & 83,88 & 35 & 100 \\
\hline
\end{tabular}

In table 3.3 , it can be seen the final test of mathematical communication skills in the Experiment class taught with WPS 6 learning each group obtained an average of 85.17 with a deviation standard of 10.667 , the minimum value is 65 and the maximum value is 100 . While with WPS learning 10 each group obtained an average of 73.45 with a standard deviation of 16.07, the minimum value is 35 and the maximum value is 100. From the average class, the average in the WPS 6 class of each group is different and higher than in the 10th WPS class of each group.

Testing the hypothesis in the first stage of testing the interaction between covariate (initial test variables) with 
learning variables, using SPSS 20 which can be seen in the following table 3.4 :

Tests of Between-Subjects Effects

Dependent Variable: Postes

\begin{tabular}{|l|r|r|r|r|r|}
\hline Source & $\begin{array}{r}\text { Type III Sum } \\
\text { of Squares }\end{array}$ & Df & \multicolumn{1}{|c|}{$\begin{array}{c}\text { Mean } \\
\text { Square }\end{array}$} & F & Sig. \\
\hline Corrected & $7069,490^{\mathrm{a}}$ & 3 & 2356,497 & 37,238 &, 000 \\
Model & 36129,399 & 1 & 36129,399 & 570,934 &, 000 \\
Intercept & 47,372 & 1 & 47,372 &, 749 &, 393 \\
Metode & 6646,160 & 1 & 6646,160 & 105,026 &, 000 \\
Pretes & 373,539 & 1 & 373,539 & 5,903 &, 021 \\
Metode * & 2151,562 & 34 & 63,281 & & \\
Pretes & 272000,000 & 38 & & & \\
Error & 9221,053 & 37 & & & \\
Total & Corrected & & & \\
Total & & & & & \\
\hline
\end{tabular}

a. R Squared $=, 767$ (Adjusted R Squared $=, 746$ )

In the table above the results of the analysis show that the value of $\mathrm{F}$ on the method line * pretest is $5.903>4.17$ with a significant $0.021<0.05$ thus $\mathrm{H} 0$ is rejected, in other words there is an interaction between method variables and test variables on the ability of students' mathematical communication.

In the second stage, a covariance analysis test is done as in table 4.27:

Tests of Between-Subjects Effects

Dependent Variable: Postes

\begin{tabular}{|l|r|r|r|r|r|}
\hline Source & $\begin{array}{r}\text { Type III Sum } \\
\text { of Squares }\end{array}$ & df & \multicolumn{1}{|c|}{$\begin{array}{c}\text { Mean } \\
\text { Square }\end{array}$} & F & Sig. \\
\hline Corrected & $6695,951^{\mathrm{a}}$ & 2 & 3347,976 & 46,406 &, 000 \\
Model & 35876,520 & 1 & 35876,520 & 497,278 &, 000 \\
Intercept & 6499,343 & 1 & 6499,343 & 90,086 &, 000 \\
Pretes & 304,601 & 1 & 304,601 & 4,222 &, 047 \\
Metode & 2525,101 & 35 & 72,146 & & \\
Error & 272000,000 & 38 & & & \\
Total & 9221,053 & 37 & & & \\
Corrected & & & & \\
Total & & & & \\
\hline
\end{tabular}

a. $\mathrm{R}$ Squared $=, 726$ (Adjusted R Squared $=, 711$ )

The significant number of pretest variables is $0.00<0.05$, so $\mathrm{H} 0$ is rejected. This means that at a $95 \%$ confidence level there is a linear relationship between pretest and students' mathematical communication skills. This means that covariance analysis requires linearity between variables to be fulfilled.

To see the effect of learning with WPS 6 and WPS 10 methods on students' mathematical communication skills in the table, it can be seen that the significant number 0.047 $<0.05$ thus $\mathrm{H} 0$ is rejected. This means that at a $95 \%$ confidence level there is an effect of different learning methods on students' mathematical communication skills. While the significant number in the Corrected Model is 0,000 $<0,05$ thus $\mathrm{H} 0$ is rejected. This means that at the level of $95 \%$ of the pretest and the different learning methods of WPS 6 and WPS 10 , it simultaneously has an effect on students' mathematical communication skills. It can be concluded that there is a significant influence of the learning model with the Write Pair Switch method on students' mathematical communication skills.

\section{CONCLUSION}

Based on the results of the analysis and findings of researchers from the field about the influence of students' mathematical communication skills and student learning interactions through write pair switch method consisting of 6 students in a group and write pair switch method consisting of 10 students in a group, obtained some conclusions which are answers to the questions in the problem formulation, including:

1. There is a significant effect of the Write Pair Switch learning method on students' mathematical communication skills.

2. The results of students 'answers in mathematical communication skills in groups consisting of 6 more students who get complete grades, and groups consisting of 10 students get more complete scores on students' answers based on each indicator of mathematical communication skills. More writing indicators were obtained in groups consisting of 6 students, indicators of drawing and mathematical expressions were obtained more in groups consisting of 10 students in the group

\section{REFERENCES}

[1] Amir, Zubaidah MZ. 2013. Perspektif Gender dalam PembelajaranMatematika. Jurnal Perempuan, Agama dan Gender. Bandung

[2] Hasratuddin. 2013. Membangun Karakter Melalui Pembelajaran Matematika. Paradikma Jurnal Pendidikan Matematika.. Vol 6 Nomor 2, hal 130-141. Medan

[3] Hasratuddin.2016. Pengembangan Program Pembelajaran Matematika (P3M). Unimed Pres. Medan

[4] Husnah, Nida Ul, dan Edy Surya. 2017. The Effectiveness of Think Talk Write Learning Model in Improving Students' Mathematical Communication Skills at MTs Al Jami'yatul Washliyah Tembung. International Journal of Sciences: Basic and Applied Research (IJSBAR). ISSN 2307-4531. Indonesia

[5] Hurst, Beth., Randall Wallace., Sarah B. Nixon. 2013. The Impact of Social Interaction on Student Learning. Reading Horizons.Volume 52.Issue 4 
[6] Jacobs, G. M. (2004). Cooperative learning: Theory, principles, and techniques. . Paper presented at the First International Online Conference on Second and Foreign Language Teaching and Research. [Online]

http://www.readingmatrix.com/conference/pp/proceedings/jacobs.pdf]h ttp://www.georgejacobs.net

[7] Jacobs, G. M., Kimura, H. (2013). Cooperative Learning and Teaching. TESOL International Association:

TESOL Press [Online] diakses pada tanggal 8 November 2017 http://www.tesol.org/BookLanding?productID=059

[8] Jacobs, G. M., Power, M. A., Loh, W. I. (2002). The teacher's sourcebook for cooperative learning: Practical techniques, basic principles, and frequently asked questions. Thousand Oaks, CA: Corwin Press http://corwinpress.com/book.aspx?pid=7905

[9] Kagan, S.(1999).Cooperative Learning: Seventeen Pros and Seventeen Cons Plus Ten Tips for Success. San Clemente, CA: Kagan Publishing [Online] diakses pada tanggal 18 Oktober 2017. http://www.kaganonline.com

[10] Ramanda, Peni dan Syahniar. 2017. Interaksi Sosial Siswa Berprestas dalam belajar. Konselor. ISSN:1412-9760.VOL.6 NO 2. Padang

[11] Rambe Nisa, Khairatun dan Edi Surya. 2017. Pengaruh Problem Learning (PBL) Terhadap Kemampuan Komunikasi Matematika Siswa. Research Gates. Medan 